REPORTS OF MORPHOLOGY
Official Journal of the Scientific Society of Anatomists,
Histologists, Embryologists and Topographic Anatomists
of Ukraine
journal homepage: https://morphology-journal.com

\title{
Pharmacological correction of various morphological forms of oral mucositis in patients with leukemia
}

\author{
Lysenko D.A. ${ }^{1}$, Lukianovych O.I. ${ }^{2}$, Sergyeyev S.V. ${ }^{1}$, Bobrowska O.A. ${ }^{1}$, Gurova 0.0. ${ }^{3}$ \\ ${ }^{1}$ National Pirogov Memorial Medical University, Vinnytsya, Vinnytsia, Ukraine; \\ ${ }^{2}$ Vinnitsa Regional Pathoanatomical Bureau, Vinnytsia, Ukraine; \\ ${ }^{3}$ Vinnytsia Regional Clinical Hospital n.a. M.I. Pirogov, Vinnytsia, Ukraine
}

\section{ARTICLEINFO \\ Received: 20 February, 2019 \\ Accepted: 22 March, 2019}

UDC: $616.311-002.44-02-085.277 .3-$ 08-039.71

\section{CORRESPONDING AUTHOR \\ e-mail: bastyl@bigmir.net} Lysenko D.A.
Oral mucositis (OM) is a common complication against the background of modern leukemia therapy, which significantly impairs patients' quality of life. The purpose of the study was to evaluate the effectiveness of the use of local Cyanocobalamin and Decamethoxine therapy for the prevention and treatment of $\mathrm{OM}$. The study was conducted on the basis of the hematology department of Vinnytsia Regional Clinical Hospital n.a. M.I. Pirogov in 2013-2019 (58 patients were studied with standard combination chemotherapy with Cytarabine, Methotrexate and anthracycline antibiotics). In addition to the standard clinical and laboratory study, dental examination was performed before treatment, at 7 and 14 days of treatment with determination of the degree of mucositis according to the NCl-CTC criteria and determination of quality of life indicators. At the same time, a sample incisional biopsy of the oral mucosa was performed with photofixation of histopreparations. In a group of 28 patients, 7 days orally administered a combination of Septefril (Decamethoxine) $0.2 \mathrm{mg}$ 4-6 times daily, and Cyanocobalamin $500 \mathrm{mg} 3$ times daily. Statistical processing of the obtained results was carried out in the license package "STATISTICA 6.1" using non-parametric methods of evaluation of the obtained results. Prior to the onset of cytostatic therapy, no signs of inflammatory lesions were reported. However, patients with pre-established signs of caries, periodontal disease and lack of teeth subsequently experienced OM, even with the use of Cyanocobalamin and Septefril. Thus, after 7 days in 8 patients on the background of medication correction I-II degree of OM according to NCI-CTC was recorded, and only in 2 - III degree, unlike the group without correction. In the group where this combination of drugs was used, OM was recorded after 7 days in 12 patients, in contrast to the indices where the correction was not performed and the development of OM had a more pronounced course and was present in all patients. According to the morphological study, several degrees of OM were observed in patients. Initially, catarrhal stomatitis with pronounced plethora and swelling of the mucous membrane was detected. During the transition to the second stage of mucositis, the aphthous stomatitis was morphologically observed, as well as dead epithelial cells and the cells undergoing parakeratotic transformation. After the application of the proposed therapy, erosion remained after the film rejection, which recovered without scarring. Thus, cytostatic therapy in patients with leukemia always causes manifestations of $O M$, which are more pronounced in patients with concomitant risk factors. The use of a combination of Cyanocobalamin and Septefril significantly reduces the manifestation of OM and improves the quality of life of patients against cytostatic therapy.

Keywords: cytostatic therapy, oral mucositis, Septefril, Cyanocobalamin, quality of life, morphological examination.

\section{Introduction}

Oral mucositis (OM) is a common complication that develops against the background of modern leukemia therapy, significantly impairing the quality of life of patients, leading to the need to discontinue treatment of the underlying disease and the appointment of concomitant treatment [10]. Despite the emergence of new targeted therapies for 
leukemia, OM remains a frequent complication and, while continuing to significantly affect the patient's condition, requires active therapeutic tactics $[9,16]$. This problem is constantly in the focus of attention of pathomorphologists, in order to obtain new data on the pathogenetic features of the emergence and course of OM. This will provide an opportunity to offer new methods of treatment for hematologists, dentists, pharmacologists [11, 16]. According to many studies, with standard cytostatic treatment, the frequency of OM was $80-90 \%$, and in high-dose chemotherapy - up to $100 \%$ of patients had manifestations of this complication [7, 10].

At the same time, inadequate oral hygiene, neutropenia, the elderly, progression of the underlying disease was among the aggravating factors contributing to exacerbation of OM [2, 8]. Accordingly, at the cellular level, factors of impaired OM development were damage to epithelial cells, development of local inflammation with induction of apoptosis of cells of different layers of the mucosa [1, 10]. As a consequence, additional infectious agents penetrate into the depths of the mucosa through the damaged epithelium, the rapid spread of which is due to cytostatic immunosuppression [3, 9]. Thus, the development of OM, as a phenomenon with complex pathogenetic character, requires complex therapy $[20,21]$.

To date, the recommendations and guidelines for cytostatic treatment observed the actual absence of a consistent algorithm for the prevention and treatment of $\mathrm{OM}$ $[6,20]$. Among the remedies recommended for the prevention and treatment of $\mathrm{OM}$ include: caphosol, zinc sulfate, povidone iodide, palifermin as a topical cytostimulatory factor, cryotherapy, other local antiinflammatory drugs, vitamin complexes $[5,13,14,15,19]$. However, their use does not fully control the occurrence and course of OM. And this is the reason for the further search for both new pharmacological agents and the use of well-known medicines [10].

Based on our own previous research, the decision was made to combine topical use of cyanocobalamin and decamethoxine as a pathogenetic effect on infectious pathogens that triggered the development of OM in the event of damage to the oral mucosa. After all, vitamin B12 (cyanocobalamin), being a well-known factor in the stimulation of DNA synthesis, which is particularly vulnerable to the action of cytostatics, in combination with decamethoxine, a drug with proven antiseptic effect on the oral flora $[11,18]$.

A complicating factor for the development of effective OM therapy regimens is the lack of data on the clinical and morphological features of the course of this complication, as well as the lack of clear criteria for both diagnosis and treatment effectiveness $[9,10]$.

The aim of the study is to evaluate the clinical and morphological features and effectiveness of local cyanocobalamin and decamethoxine therapy for the prevention and treatment of OM.

\section{Materials and methods}

The study was conducted at the hematology department of Vinnitsa Regional Clinical Hospital in 2013-2019. The study monitored 58 patients receiving standard combination cytostatic chemotherapy using cytarabine, methotrexate and anthracycline antibiotics [17]. All patients were divided into the following observation groups: 23 of them had acute myeloid leukemia; 20 acute lymphoid leukemia; the remaining 15 are other oncohematological diseases. Treatment protocols for all patients included the use of combined cytostatic chemotherapy. Observed patients ranged in age from 18 to 60 years, including 30 women and 28 men. Patients were divided into 2 comparison groups, randomization was blind in nature to maintain compliance. In addition to the standard clinical and laboratory examination, a dental examination was performed to determine the degree of mucositis according to the $\mathrm{NCl}$ CTC criteria and to examine the quality of life indices according to the methodology proposed by us earlier [12]. The production of histological preparations from the affected areas of the oral mucosa was performed according to the standard method, including incisional biopsy, fixation of small pieces of material in $10 \%$ buffered formalin solution. The paraffin sections obtained on the dome microtome are processed in three steps: dehydration, deparaffinization and staining with hematoxylin-eosin followed by confinement in polystyrene. The results of the study were recorded using an Olympus B-41 light microscope with an Olympus E-410 digital camera.

Dental checkpoints were 0 days of therapy, 7 and 14 days of treatment. A group of 28 patients was prescribed a combination of $0.2 \mathrm{mg}$ septefril (decamethoxine) 4-6 times a day and orally $500 \mathrm{mg}$ cyanocobalamin 3 times a day for 7 days. In 30 patients, no specific local treatment was performed. All studies were performed with the informed consent of the patients.

Statistical processing of the obtained results was performed in the license package "STATISTICA 6.1" using non-parametric methods of estimation of the obtained results according to the recommendations of $F$. Bonnetain and others [4]. The correctness of the distribution of traits by each of the variations obtained, the mean values of each trait studied and the standard deviation were evaluated. The significance of the difference in values between the independent quantitative values was determined using the Mann-Whitney U test.

\section{Results}

The previous distribution of groups showed that by age, gender representation and administration of cytostatic drugs we maintained the representativeness and randomization of groups.

The age distribution of both groups from 18 to 60 years was due to recommendations for high-dose cytostatic therapy only in patients less than 60 years of age. In patients over 60 years of age, this mode of cytostatic therapy has no 
benefits in terms of results and significantly increases the risk of side effects and even recorded an increase in mortality with prolonged use.

The mean age of patients in both groups was 45 and 48 years. The correction and non-medication group, therefore, did not have a significant age difference that could not be a risk factor for OM. During the dental examination, no signs of inflammatory lesion of the oral mucosa were detected prior to the initiation of cytostatic therapy in all patients examined. However, in 10 and 9 patients in the group with correction and without, respectively, pre-established signs of caries, periodontal disease and uncorrected absence of teeth, which are recognized [11] risk factors for OM were found. It should be noted that all of these patients subsequently experienced $O M$, even when using a combination of cyanocobalamin and septefril. However, when using this combination after 7 days in 8 patients on the background of correction I-II degree of OM according to NCI-CTC was recorded and only in 2 - III degree. Unlike in the group without correction, no cases of grade I stomatitis were detected in 9 patients without correction on the background of dental pathology. According to the NCI-CTC, all cases of OM in this group showed signs of grade II-III, which was confirmed by histological examination. This difference indicates that there is a protective effect of the proposed combination of drugs in the presence of the patient of this risk factor for OM.

All patients in both groups had moderate and severe neutropenia according to the NCCN Clinical Practice Guidelines in Oncology criteria [20], with no significant differences in leukocyte counts after 7 and 14 days, following standard cytostatic therapy. Given the nosological diversity and differences of cytostatic therapy of individual nosologies, we did not analyze the leukocyte formula in all patients studied. It should also be noted that granulocytemacrophage colony-stimulating factors were standardized to achieve $1.5 \times 109 / \mathrm{L}$ leukocyte levels in all patients with neutropenia, as recommended by national and international protocols $[6,17,20]$. In the case of neutropenic fever, which was recorded in 27 out of 28 and 29 out of 30 patients of the respective groups, standardized antibacterial therapy was also prescribed $[6,20]$, which did not affect the development and course of $\mathrm{OM}$. This can be explained by the appearance of neutropenic fever 10-12 days after the start of cytostatic therapy, and histological signs of OM were recorded from the 7 day of therapy. We will also note that patients have noted clinical manifestations of oral irritation at 4-5 days from the beginning of treatment.

That is, all the patients we examined had this risk factor for OM, and a further discrepancy in the frequency and course of this complication was only due to the use of a combination of cyanocobalamin and septefril. In general, OM in the group where the use of this combination was recorded after 7 days in 12 patients, in contrast to the group $(p<0.05)$, where no medical correction was performed and the development of OM had a more severe course and was found in all patients.
Also, according to our findings, quality of life indicators was reduced in the group that did not use a combination of cyanocobalamin and septefril. In particular, the overall quality of life score in the group using the above scheme after 7 days was $57 \pm 12$ points, and without the combination - $34 \pm 7$ points $(p<0.05)$. Among the components of quality of life, the indicators of role social functioning of 2.7 points in the group without correction were the lowest and 11 points with correction $(p<0.05)$. After 14 days, the quality of life indicators and their constituents did not differ significantly in the two groups.

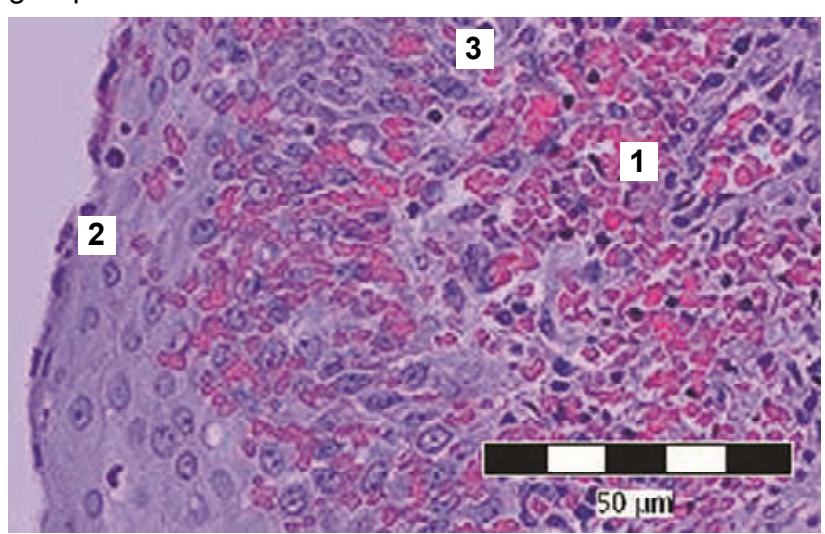

Fig. 1. Catarrhal mucositis. There is hemorrhage into the epithelial layer of the mucous membrane (1), dyskeratosis of the integumentary squamous epithelium (2), single segmented nucleotides (3). Hematoxylin-eosin. x400.

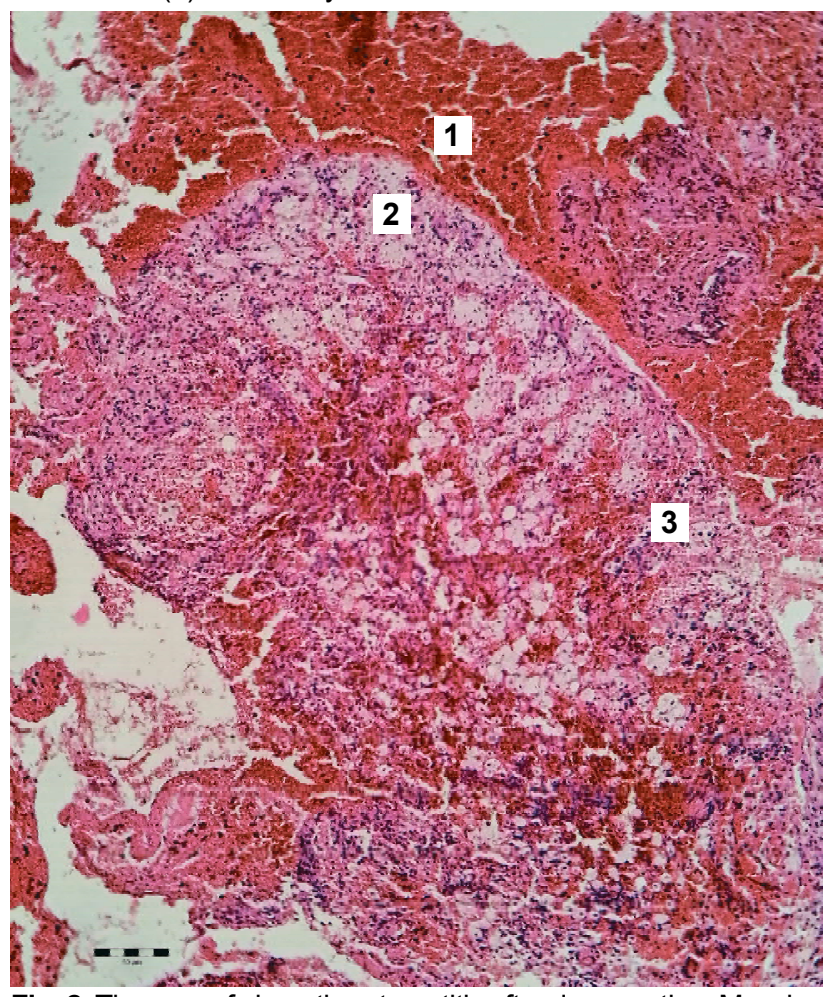

Fig. 2. The area of ulcerative stomatitis after demarcation. Massive hemorrhages (1), dystrophically altered cells, sharp swelling of the submucosal base (2), tissue detritus with cells of inflammatory infiltration (3). Hematoxylin-eosin. x200. 


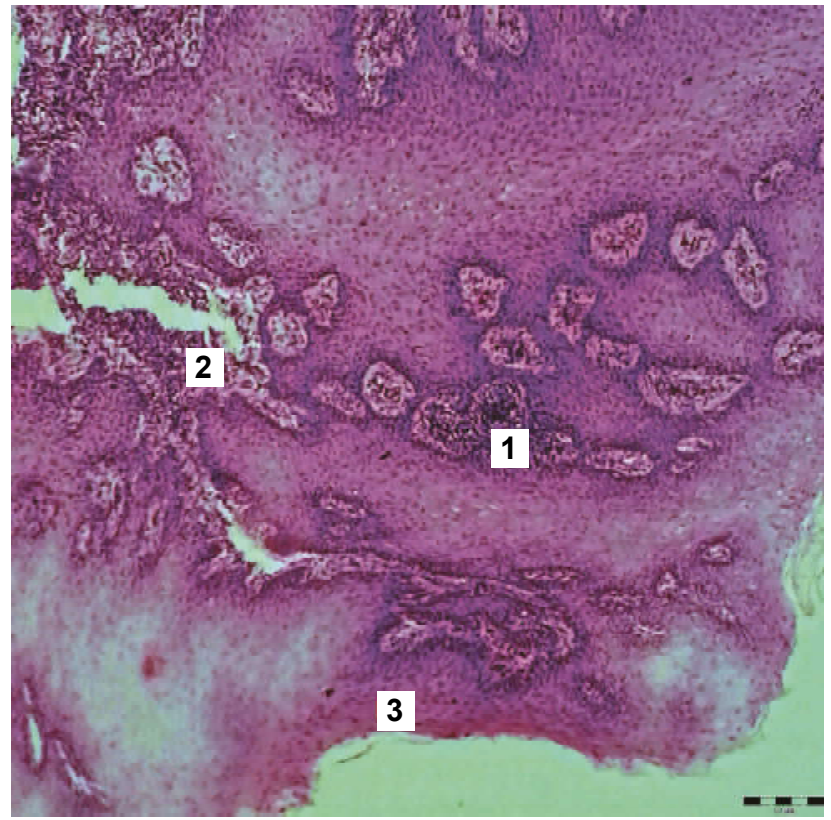

Fig. 3. Catarrhal mucositis with signs of reparation. Foci of inflammatory infiltration in the submucosa involving the squamous epithelium (1), tangles of thin-walled full-blood vessels forming granulation glomeruli (2), dyskeratotic changes of the superficial layers of the squamous epithelium (3). Hematoxylin-eosin. x200.

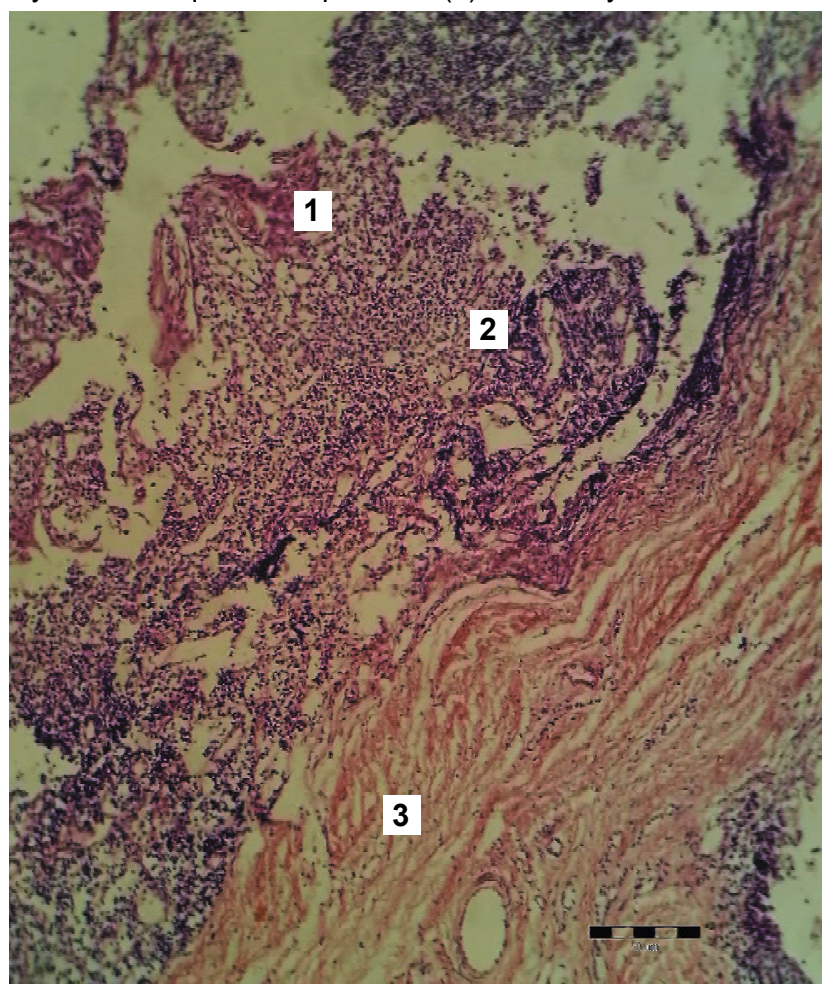

Fig. 4. Ulcerative mucositis. Active ulcer, perifocal inflammation with a large number of segmented neutrophils, tissue detritus (1), dyskeratotic phenomena in desquamated epithelium (2). Severe submucosal edema (3). Hematoxylin-eosin. x200.

Histological examination revealed that I-II degree of OM according to $\mathrm{NCl}-\mathrm{CTC}$ corresponded to catarrhal

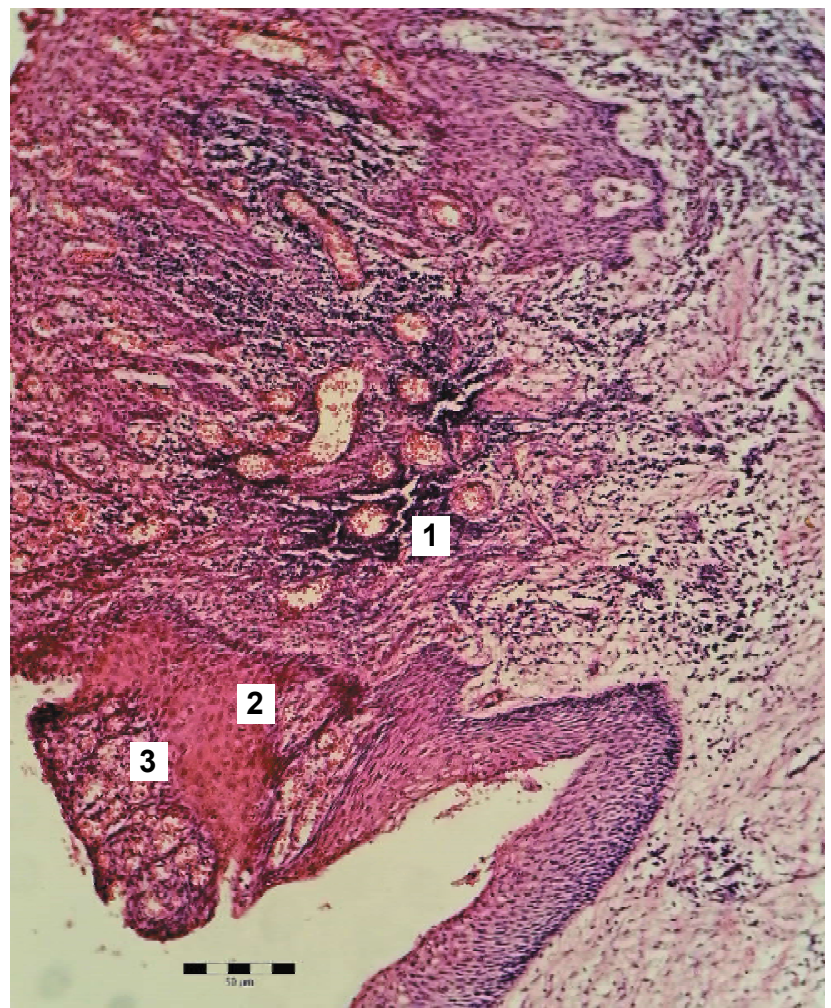

Fig. 5. Hyperplastic reaction in the area of uncorrected absence of tooth. Purulent-proliferative inflammatory reaction with the area of ulceration (1). Hyper- and parakeratosis of the squamous epithelium (2). Granulation tissue (3). Hematoxylin-eosin. x200.

inflammation (Fig. 1).

Catarrhal mucositis in macroscopic examination was characterized by pronounced plethora and swelling of the mucous membrane. The desquamated epithelium accumulated on the lips and tongue in the form of a thick, dirty gray in color, layer. Microscopically, the surface of the mucous membrane was covered with serous exudate with impurities of segmented neutrophils. Also, a significant amount of mucus was determined, which was strongly secreted by the glandular cells of the mucous membrane. Desquamated cells of the superficial layers of the epithelium were present, both keratinized and alive, many of which with dystrophic changes, the phenomena of dyskeratosis and parakeratosis. Depending on the nature of the exudate and the prevalence of mucus, leukocytes, or fused cells, it could be referred to sero-mucoid, purulent or desquamative catarrh (Fig. 2).

With a large number of leukocytes that have passed through the epithelium, macroscopic opacification of the mucous membrane is observed, masking inflammatory redness. However, the majority of patients had a pattern of minor local inflammation due to neutropenia. The use of the proposed combination of cyanocobalamin and septefril alters the course of cytostatic mucositis at the morphological level (Fig. 3).

In the development of ulcerative mucositis, we found 
the appearance of hyperemic, swollen mucous membrane, limited areas of necrosis of grayish-yellow color, which represent foci of necrotic or necrotic-fibrinous inflammation (Fig. 4). The rejection or melting of necrotic areas leads to the formation of ulcers. Ulcerative mucositis is particularly characteristic of the gangrenous disintegration of dead tissue sections, in which spirochetes and spindle-shaped sticks are observed. After demarcation and rejection of the dead tissue sections, the ulcers are filled with granulations, their scarring and recovery of the epithelial layer occurs (Fig. 5).

We also note that we observed a clear correspondence between the degree of clinical manifestations of OM, quality of life and histological examination data, in our opinion, the classification of $\mathrm{NCl}-\mathrm{CTC}$ should be supplemented given the complex results we received, which will allow to differentiate more clearly the manifestations of this complication and to predict further therapeutic management.

\section{Discussion}

The small sample size of the study does not allow us to conclude on the expediency of standardized use of the proposed combination of drugs. Also, for the sake of proof, a comparison of this regimen with the previously proposed drugs should be made. Similar studies have already been conducted regarding the use of topical antiseptic agents, recombinant keratinocyte growth factor (palifermin), and other means of preventing and treating of OM $[6,7,8,9,10]$.

There is no doubt about the importance of the prevention of mucositis. According to the data obtained by us and other researchers $[5,15,19]$, the presence of risk factors requires careful dental examination and correction prior to cytostatic therapy. But even the absence of these factors or their correction does not reduce the percentage of manifestations of OM in this category of patients in the treatment of patients with leukemia with high doses of cytostatic drugs. In particular, as established in our study, it is consistent with the data obtained in similar works $[5,19]$, devoted to the study of clinical manifestations of OM against the use of cytostatic agents. In our opinion, this issue requires further study to identify possible latent risk factors for the development of $\mathrm{OM}$ in patients with oncohematologic pathology.

Also, the use of preventive agents has a significant positive effect on the quality of life of patients, which has been recorded, both in our study and in similar studies devoted to the prevention and treatment of OM [2, 3]. Given that this complication is frequent and significantly affects

\section{References}

[1]Ahmad, P., Akhtar, U., Chaudhry, A., Rashid, U., Saif, S., \& Asif, J. A. (2019). Treatment and prevention of oral mucositis: A literature review. European Journal of General Dentistry, 8(2), 23. doi: 10.4103/ejgd.ejgd_30_19

[2] Basile, D., Di Nardo, P., Corvaja, C., Garattini, S. K., Pelizzari, G., Lisanti, C., \& Gerratana, L. (2019). Mucosal Injury during Anti- patients, the prevention and treatment of $\mathrm{OM}$ is an important aspect of concomitant treatment of oncohematologic patients. For concomitant therapy, the primary goal is to improve quality of life, and quality of life indicators are important indicators of the effectiveness of this link in therapy [4].

Attention is drawn to the lack of common protocols, especially at the national level, on the conduct of OM. Stratification of risk factors, reasonable prevention and treatment measures will significantly improve the quality of life of patients, even with high dose cytostatic therapy and at risk groups. It is also necessary to analyze the morphological manifestations of $\mathrm{OM}$ and the clinical features of this complication, in order to clearly identify possible risk groups early and further develop recommendations for the prevention of this complication. At present, there are no detailed recommendations [8, 9, 11], considering histological manifestations and clinical features, since the existing ones do not consider the complexity of this lesion.

We also emphasize the urgent need for further study of the various groups of drugs that may prevent the development of oral mucositis and the development of optimal measures for the prevention and therapy of oral mucositis. This trend is relevant according to the current trends of scientific research on the study of OM $[9,10,11]$.

Also, in our opinion, the existing classification of OM according to NCI-CTC, which does not consider the peculiarities of clinical manifestations of this complication and quality of life indicators, requires detail and further refinement. Histological examinations allow verifying the $\mathrm{OM}$ and its extent, but it is also necessary to clarify the prognostic value of these studies in order to improve prevention and therapy and rational choice of treatment regimen.

The prospect of further developments is to clarify the clinical and morphological manifestations of OM on the background of different modes of cytostatic therapy and to evaluate the effectiveness of treatment regimens and prevention of oral mucositis.

\section{Conclusions}

1. Cytostatic therapy in patients with leukemia always causes manifestations of grade I-II OM according to $\mathrm{NCl}$ CTC.

2. More pronounced clinical and morphological manifestations of OM are observed in patients with risk factors.

3. The use of a combination of cyanocobalamin and septefril significantly reduces the manifestation of $\mathrm{OM}$ and improves the quality of life of patients against cytostatic therapy.

Cancer Treatment: From Pathobiology to Bedside. Cancers, 11(6), 857. https://doi.org/10.3390/cancers 11060857

[3] Blakaj, A., Bonomi, M., Gamez, M. E., \& Blakaj, D. M. (2019). Oral mucositis in head and neck cancer: Evidence-based management and review of clinical trial data. Oral oncology, 95, 29-34. https://doi.org/10.1016/j.oraloncology.2019.05.013 
[4] Bonnetain, F., Fiteni, F., Efficace, F., \&Anota, A. (2016). Statistical Challenges in the Analysis of Health-Related Quality of Life in Cancer Clinical Trials. Journal of clinical oncology: official journal of the American Society of Clinical Oncology, 34(16), 1953. https://doi.org/10.1200/JCO.2014.56.7974

[5] Bradstock, K. F., Link, E., Collins, M., Di lulio, J., Lewis, I. D., Schwarer, A., \& Cull, G. (2014). A randomized trial of prophylactic palifermin on gastrointestinal toxicity after intensive induction therapy for acute myeloid leukaemia. British journal of haematology, 167(5), 618-625. https:// doi.org/ 10.1111/bjh.13086

[6] Brown, P. A., Wieduwilt, M., Logan, A., DeAngelo, D. J., Wang, E. S., Fathi, A., \& Bhatnagar, B. (2019). Guidelines Insights: Acute Lymphoblastic Leukemia, Version 1.2019: Featured Updates to the NCCN Guidelines. Journal of the National Comprehensive Cancer Network, 17(5), 414-423. https:// doi.org/10.6004/jnccn.2019.0024

[7] Carrozzo, M., Eriksen, J. G., Bensadoun, R. J., Boers-Doets, C. B., Lalla, R. V., \& Peterson, D. E. (2019). Oral Mucosal Injury Caused by Targeted Cancer Therapies. JNCI Monographs, (53), lgz012. https://doi.org/10.1093/jncimonographs/lgz012

[8] Chaveli-López, B., \& Bagán-Sebastián, J. V. (2016). Treatment of oral mucositis due to chemotherapy. Journal of clinical and experimental dentistry, 8(2), e201-9. doi: 10.4317/jced.52917

[9] Cidon, E. U. (2017). Chemotherapy induced oral mucositis: prevention is possible. Chinese clinical oncology, 7(1), 6 . doi: 10.21037/cco.2017.10.01

[10] Cinausero, M., Aprile, G., Ermacora, P., Basile, D., Vitale, M. G., Fanotto, V., ... \& Sonis, S. T. (2017). New Frontiers in the Pathobiology and Treatment of Cancer Regimen-Related Mucosal Injury. Frontiers in pharmacology, 8, 354. doi: 10.3389/fphar.2017.00354

[11] Daugèlaitè, G., Užkuraitytè, K., Jagelavičienè, E., \& Filipauskas, A. (2019). Prevention and Treatment of Chemotherapy and Radiotherapy Induced Oral Mucositis. Medicina, 55(2), 25. doi: 10.3390/medicina55020025

[12] Isakova, L. M., \& Lysenko, D. A. (2006). Methodology of the quality of life estimation in oncohematology. Ukrainian Medical Journal, 3, 47-50.

[13] Kanagalingam, J., Chopra, A., Hong, M. H., Ibrahim, W., Villalon, A., \& Lin, J. C. (2017). Povidone-iodine for the management of oral mucositis during cancer therapy. Oncology reviews, 11(2),
341. doi: 10.4081/oncol.2017.341

[14] Kim, J. W., Kim, M. G., Lee, H. J., Koh, Y., Kwon, J. H., Kim, I., ... \& Yoon, S. S. (2017). Topical recombinant human epidermal growth factor for oral mucositis induced by intensive chemotherapy with hematopoietic stem cell transplantation: final analysis of a randomized, double-blind, placebo-controlled, phase 2 trial. PloS one, 12(1), e0168854. doi: 10.1371/ journal.pone. 0168854

[15] Mahendran, V. J., Stringer, A. M., Semple, S. J., Song, Y., \& Garg, S. (2018). Advances in the Use of Anti-inflammatory Agents to Manage Chemotherapy-induced Oral and Gastrointestinal Mucositis. Current pharmaceutical design, 24(14), 1518-1532. doi: 10.2174/ 1381612824666180409093918

[16] Mori, K., Horinouchi, M., Domitsu, A., Shimotahira, T., Soutome, S., Yamaguchi, T., \& Oho, T. (2017). Proper oral hygiene protocols decreased inflammation of gingivitis in a patient during chemotherapy with bevacizumab: a case report. Clinical case reports, 5(8), 1352-1357. doi: 10.1002/ccr3.1034

[17] Order of the Ministry of Health of Ukraine from 30.06.2010 №647. On approval of clinical protocols for the provision of medical care to patients in the specialty "Hematology". http:// moz.gov.ua/ua/portal/dn_20100730_647.html

[18] Paliy, G. K., Nazarchuk, O. A., Faustova, M. O., Pali, V. G., \& Yatsula, O. V. (2016). Investigation of the effectiveness of antimicrobials in patients with inflammatory diseases of the oral cavity. Bulletin of problems of biology and medicine, 2(3), 220-225.

[19] Rambod, M., Pasyar, N., \& Ramzi, M. (2018). The effect of zinc sulfate on prevention, incidence, and severity of mucositis in leukemia patients undergoing chemotherapy. European Journal of Oncology Nursing, 33, 14-21. doi: 10.1016/ j.ejon.2018.01.007

[20] Tallman, M. S., Wang, E. S., Altman, J. K., Appelbaum, F. R., Bhatt, V. R., Bixby, D., ... \& Foran, J. M. (2019). Acute Myeloid Leukemia, Version 3.2019, NCCN Clinical Practice Guidelines in Oncology. Journal of the National Comprehensive Cancer Network, 17(6), 721-749. https://doi.org/10.6004/ jnccn.2019.0028

[21] Villa, A., \& Sonis, S. T. (2015). Mucositis: pathobiology and management. Current opinion in oncology, 27(3), 159-164. doi: $10.1097 / C C O .0000000000000180$

\section{ФАРМАКОЛОГІЧНА КОРЕКЦІЯ РІЗНИХ МОРФОЛОГІЧНИХ ФОРМ ОРАЛЬНОГО МУКОЗИТУ У ХВОРИХ НА ЛЕЙКЕМІЮ Лисенко Д.А., Лук'янович О.І., Сергєєв С.В., Бобровська О.А., Гурова О.О.}

Оральний мукозит (OM) є частим ускладненням на фоні сучасної терапії лейкемій, що суттєво погіршує якість життя пацієнтів. Мета дослідження - оцінити ефективність використання місцевої терапії ціанкобаламіном та декаметоксином з метою профілактики та лікування ОМ. Дослідження було проведене на базі гематологічного відділення Вінницької обласної клінічної лікарні ім. М.І. Пирогова в 2013 - 2019 роках (вивчені 58 пацієнтів, зі стандартною комбінованою хіміотерапією цитарабіном, метотрексатом та антрацикліновими антибіотиками). Крім стандартного клініко-лабораторного дослідження, проводили стоматологічне обстеження до лікування, на 7 та 14 добу лікування із визначенням ступеня мукозиту за критеріями NCI-CTC та показників якості життя. Одночасно провели вибіркову інцізійну біопсію слизової оболонки ротової порожнини з фотофіксацією гістопрепаратів. У групі із 28 пацієнтів 7 діб перорально призначали комбінацію септефрилу (декаметоксину) 0,2 ме 4-6 разів на добу, та ціанокобаламіну 500 ме 3 рази на добу. Статистичну обробку отриманих результатів провели в ліцензійному пакеті "STATISTICA 6.1" із застосуванням непараметричних методів оцінки отриманих результатів. До початку цитостатичної терапії ознак запального ураження слизової оболонки порожнини рота виявлено не було. Однак, у пацієнтів з попередньо встановленими ознаками карієсу, пародонтозу та відсутністю зубів у подальщому виник ОМ, навіть при використанні ціанокобаламіну та септефрилу. Так, у 8 пацієнтів через 7 діб на фоні медикаментозної корекції була зафіксована I-II ступінь ОМ за NCl-CTC, і лише у 2 - III ступінь, на відміну від групи без корекції. В групі, де була використана дана комбінація препаратів, ОМ зафіксовано через 7 діб у 12 пацієнтів, на відміну від показників групи, де корекцію не проводили і розвиток ОМ мав більш виразний перебіг і був наявний у всіх пацієнтів. За даними морфологічного дослідження у пацієнтів спостерігали декілька ступенів ОМ. На початковій стадії виявлений катаральний стоматит із вираженим повнокрів'ям та набряком слизової оболонки. При переході в другу стадію мукозиту 
морфологічно спостерігали афтозний стоматит, а також відмерлі клітини епітелію та клітини, що підлягали паракератотичній трансформації. Після застосування запропонованої терапії та відторенення плівки залишалася ерозія, яка відновлювалась без рубцювання. Таким чином, цитостатична терапія у хворих на лейкемію завжди викликає прояви ОМ, котрі більш виразно проявляються у пацієнтів зі супутніми фракторами ризику. Застосування комбінації ціанокобаламіну та септефрилу суттєво зменшує прояви ОМ та покращує якість життя пацієнтів на фоні проведення цитостатичної терапії. Ключові слова: цитостатична терапія, оральний мукозит, септефрил, ціанокобаламін, якість життя, морфологічне дослідження.

\section{ФАРМАКОЛОГИЧЕСКАЯ КОРРЕКЦИЯ РАЗЛИЧНЫХ МОРФОЛОГИЧЕСКИХ ФОРМ ОРАЛЬНОГО МУКОЗИТА У БОЛЬНЫХ ЛЕЙКЕМИЕЙ \\ Лысенко Д.А., Лукьянович О.И., Сергеев С.В., Бобровская О.А., Гурова О.О.}

Оральный мукозит (ОМ) является частым осложнением, которое развивается на фоне современной терапии лейкемии, что существенно ухудшает качество жизни пациентов. Цель работы - оценить эфррективность использования местной терапии цианокобаламином и декаметоксином с целью профилактики и лечения различных морфологических фоорм ОМ. Исследование было проведено на базе гематологического отделения Винницкой областной клинической больницы имени Н.И. Пирогова в 2013 - 2019 годах (изучены 58 пациентов со стандартной комбинированной химиотерапией цитарабина, метотрексата и антрациклиновых антибиотиков). Кроме стандартного клинико-лабораторного обследования проводили стоматологическое обследование до лечения, на 7 и 14 сутки лечения с определением степени мукозита по критериям NCI-CTC и определением показателей качества жизни. Одновременно проведена избирательная инцизионная биопсия слизистой оболочки ротовой полости и последующая фротофриксация гистопрепаратов. В группе из 28 пациентов 7 дней перорально назначали комбинацию септефрила (декаметоксина) 0,2 ме 4-6 раз в сутки и цианкобаламина 500 ме 3 раза в сутки. Статистическая обработка полученных результатов проведена в лицензионном пакете "STATISTICA 6.1" с применением непараметрических методов оценки полученных результатов. До начала цитостатической терапии признаков воспалительного поражения слизистой оболочки ротовой полости не было обнаружено. Однако у пациентов с предварительно установленными признаками кариеса, пародонтоза и отсутствия зубов в дальнейшем возник ОМ, даже при использовании цианокобаламина и септефрила. Так, через 7 дней у 8 пациентов на фоне медикаментозной коррекции был зафиксирован ОМ I-II степени по NCI-CTC и только у 2 - III степени, в отличии от показателей группы без коррекции. В группе, где использовали вышеприведенную комбинацию препаратов, ОМ был зафиксирован у 12 пациентов через 7 суток, в отличии от показателей группы, где коррекцию не проводили и ОМ присутствовал у всех и протекал более тяжело. По данным морфологического исследования у пациентов наблюдали несколько степеней ОМ. На начальной стадии выявлен катаральный стоматит с выраженным полнокровием и отеком слизистой оболочки. При переходе во вторую стадию мукозита морфрологически наблюдали афтозный стоматит, а также омертвевшие клетки эпителия и клетки, подвергшиеся паракератотической трансформации. После применения предложенной терапии и отторжения пленки оставалась эрозия, которая восстанавливалась без рубцевания. Таким образом, цитостатическая терапия у больных лейкемией всегда вызывает проявления ОМ, которые более выражены у пациентов с сопутствующими фракторами риска. Применение комбинации цианокобаламина и септефррила существенно уменьшает проявления ОМ и улучшает качество жизни пациентов на фоне проведении цитостатической терапии.

Ключевые слова: цитостатическая терапия, оральный мукозит, септефрил, цианокобаламин, качество жизни, морфологическое исследование. 